Research Report No. 24/2010

\title{
Corporate Governance, Capital Market Regulation and the Challenge of Disembedded Markets
}

Peer Zumbansen

Osgoode Hall Law School of York University, PZumbansen@osgoode.yorku.ca

Follow this and additional works at: http:// digitalcommons.osgoode.yorku.ca/clpe

\section{Recommended Citation}

Zumbansen, Peer, "Corporate Governance, Capital Market Regulation and the Challenge of Disembedded Markets" (2010).

Comparative Research in Law \& Political Economy. Research Paper No. 24/2010.

http://digitalcommons.osgoode.yorku.ca/clpe/91 


\section{OSGOODE}

OSCOODE HALL LAW SCHOOL

YOR K UNIVERSITY

\section{OSGOODE HALL LAW SCHOOL}

Comparative Research in Law \& Political Economy

RESEARCH PAPER SERIES

Research Paper No. 24/2010

Corporate Governance, Capital Market Regulation and the Challenge of Disembedded Markets

Peer Zumbansen

Editors:

Peer Zumbansen (Osgoode Hall Law School, Toronto, Director, Comparative Research in Law and Political Economy)

John W. Cioffi (University of California at Riverside)

Lisa Philipps (Osgoode Hall Law School, Associate Dean Research)

Nassim Nasser (Osgoode Hall Law School, Toronto,

Production Editor)

Comparative Research in Law \& Political Economy

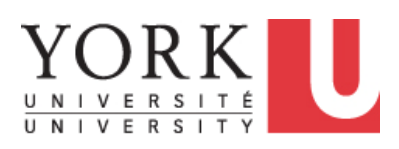


CLPE Research Paper 24/2010

Vol. 06 No. 6 (2010)

Peer Zumbansen

\title{
Corporate Governance, Capital Market Regulation and the Challenge of Disembedded Markets
}

\begin{abstract}
Long before the current financial and economic crisis, corporate governance and securities regulation had become part of one of the most interesting and dynamic regulatory areas in law and policy making today. Both areas had been undergoing dramatic transformations over the past 30-40 years, which saw a global expansion of capital markets and a deep-running 'financialisation' of the corporation. Around the world governments saw themselves challenged to adapt their regulatory apparatus to the whims and hues of nervous investors with global sensitivities. Meanwhile, scholars in law, economics, but also political science and sociology fiercely debated whether what was unfolding constituted a worldwide convergence around a corporate governance philosophy that placed the shareholder at the centre or whether we would continue to have different, divergent corporate governance systems around the world. Today's crisis-responses appear to be primarily designed to 'fix the excesses' of the past decades, rather than driven by an interest to connect the present efforts at regulation with the earlier convergence vs. divergence debates, which themselves built on much older critiques of the embeddedness of the firm and the political economy context of corporate activity. The paper contends that the sustainability of future corporate governance and securities regulation depends on the effort to critically examine both areas in the context of a larger inquiry into the goals and challenges of market regulation.
\end{abstract}

Keywords: Financial Crisis, Corporate Governance, Embeddedness, Transnational legal pluralism

JEL classification: $\mathrm{K} 10, \mathrm{~K} 22$

This chapter will appear in William Sun (ed.), Corporate Governance and the Global Financial Crisis: International Perspectives (Cambridge University Press, 2010)

Peer Zumbansen

Professor of Law.

Canada Research Chair in Transnational Economic Governance and Legal Theory.

Director, Critical Research Laboratory, Osgoode Hall Law School, York University, Toronto.

2009-2010 Visiting Professor, University College Dublin, School of Law.

Email: Pzumbansen@osgoode.yorku.ca. 


\title{
Corporate Governance, Capital Market Regulation and the Challenge of Disembedded Markets*
}

\author{
Peer Zumbansen**
}

\section{IntRoduction: Corporate GovernanCE AND the FinanCIAL CRISIS}

Long before the present investigations into the role of corporate governance regulation in the coming of the financial crisis $^{1}$, corporate law had become a highly dynamic regulatory laboratory for the study of a fast transforming body of norms governing corporate activities worldwide. The immense attention that the field has been attracting over the past thirty years from legal scholars, economists, political scientists, sociologists and even psychologists ${ }^{2}$ amply testifies to the increasingly interdisciplinary nature of the corporate governance. Partly, this development is owed to the dramatic transformation of corporate law over the recent past, mostly influenced by the rapid expansion of global capital markets, which have placed enormous pressure on the different existing national legal cultures pertaining to company law, labour law and industrial relations regulation. The international competition over investment and the innovation of ever-new and more flexible financial instruments have over time induced a fundamental transformation of corporate governance that is frequently referred to as a rise of 'financialism' ${ }^{3}$ and which has lead to a far-reaching change in the understanding of the

\footnotetext{
* This chapter builds on: P. Zumbansen 2010. 'The Next 'Great Transformation'? The Double Movement in Transnational Corporate Governance and Capital Markets Regulation', in C. Joerges and J. Falke (eds), The Social Embeddedness of Transnational Markets. Oxford, Uk \& Portland, OR, Hart Publishing, pp. forthcoming, and on P. Zumbansen 2009. "New Governance' in European Corporate Governance Regulation as Transnational Legal Pluralism', European Law Journal 15: pp. 246-276 [available at http://ssrn.com/abstract=1128145]. It was written during my visit at University College Dublin 2009-2010 and my June-August 2010 Fellowship at the Hanse Institute of Advanced Study. I am grateful for conversations on the topic to Blanaid Clarke and Colin Scott.

** Professor of Law. Canada Research Chair in Transnational Economic Governance and Legal Theory. Osgoode Hall Law School, York University, Toronto. 2009-2010, Visiting Professor in Transnational Law and Corporate Governance, University College Dublin. Email: Pzumbansen@osgoode.yorku.ca
}

${ }^{1}$ B. R. Cheffins 2009. 'Did Corporate Governance "Fail" during the 2008 Stock Market Meltdown? The Case of the S\& P 500', Business Lawyer 65: pp. 1-62

${ }^{2}$ See eg R. Aguilera, D. Rupp, C. A. Williams and J. Ganapathi 2004. 'Putting the S Back in Corporate Social Responsibility: a Multi-Level Theory of Social Change in Organizations', Academy of Management Review 32: pp. 836-863 [http://papers.ssrn.com/so/833/papers.cfm?abstract_id=567842]

${ }^{3}$ L. E. Mitchell 2010. 'Financialism - A (Very) Brief History', in P. Zumbansen and C. A. Williams (eds), The Embedded Firm: Corporate Governance, Labour and Financial Capitalism. Cambridge, UK, Cambridge University Press, pp. forthcoming; P. Zumbansen 2010. 'The New Embeddedness of the Corporation: Corporate Social Responsibility in 
business corporation from an organizational entity geared towards economic growth to an investment vehicle with a very particular set of expectations attached to it. ${ }^{4}$ The nature and consequences of this transformation have been a constant cause of dispute: whereas one camp has been voicing, in sometimes triumphalist mode $^{5}$, the inevitable convergence of corporate governance systems towards a model focused on shareholder value maximization ${ }^{6}$, scholars in the other camp have been questioning this alleged convergence on the basis of a host of different sets of evidence, drawing on comparative political economy ${ }^{7}$, comparative company law $^{8}$ and historical research. ${ }^{9}$ Taken together, until just about the outbreak of the financial crisis, 'corporate governance' had no doubt become one among the most interesting instances for an interdisciplinary study of how market regulation rules unfold, are administered and governed. Such investigations emerged against the background of an increasingly rich body of comparative research ${ }^{10}$ and branched out into fascinating inquiries into the changing modes of corporate organisation, corporate finance and corporate 'democracy' on the one hand ${ }^{11}$, and

the Knowledge Society', in P. Zumbansen and C. A. Williams (eds), The Embedded Firm: Corporate Governance, Labour and Financial Capitalism. Cambridge, UK, Cambridge University Press, pp. forthcoming

${ }^{4}$ W. Lazonick 1991. Business organization and the myth of the market economy, Cambridge University Press, ch. 3

${ }^{5}$ The most explicit contribution was surely: H. Hansmann and R. Kraakman 2001. 'The End of History for Corporate Law', Georgetown Law Journal 89: pp. 439-468; see also H. Hansmann 2006. 'How Close is the End of History?' Journal of Corporate Law 31: pp. 745-750.

${ }^{6}$ R. Kraakman, P. L. Davies, H. Hansmann, G. Hertig, K. J. Hopt, H. Kanda and E. B. Rock 2004. The Anatomy of Corporate Law. A Comparative and Functional Approach, 2nd ed. 2009, Oxford University Press

${ }^{7}$ S. Vitols 2001. 'Varieties of Corporate Governance: Comparing Germany and the UK', in P. A. Hall and D. Soskice (eds), Varieties of Capitalism. The Institutional Foundations of Comparative Advantage. Oxford/New York, Oxford University Press, pp. 337-360; J. W. Cioffi 2006. 'Corporate Governance Reform, Regulatory Politics, and the Foundations of Finance Capitalism in the United States and Germany', German Law Journal 7: pp. 533-562

${ }^{8}$ M. M. Siems and S. Deakin 2009. 'Comparative Law and Finance: Past, Present and Future Research', Journal of Institutional and Theoretical Economics pp. http://ssrn.com/abstract=1428247

${ }^{9}$ S. Deakin 2010. 'Corporate Governance and Financial Crisis in the Long Run', in P. Zumbansen and C. A. Williams (eds), The Embedded Firm: Corporate Governance, Labour and Financial Capitalism. Cambridge, UK, Cambridge University Press, pp. forthcoming

${ }^{10}$ See the excellent overview by K. J. Hopt 2006. 'Comparative Company Law', in M. Reimann and R. Zimmermann (eds), Oxford Handbook of Comparative Law. Oxford/New York, Oxford University Press, pp. 1161-1191. 
into the particular nature of norms that govern corporate behaviour on the other. ${ }^{12}$ All along, the political dimensions of such research were anything but invisible: large-scale corporate scandals around firms such as Enron or Parmalat ${ }^{13}$, headline-making transnational take-overs such as the Mannesmann-Vodafone deal ${ }^{14}$ or the public concern over management compensation $^{15}$ had long illustrated the political connotations of corporate governance regulation. ${ }^{16}$ Remarkable, however, in this debate was the discrepancy between a seemingly instant public outrage in the face of blatant corporate misdeeds and a relative amnesia with regard to the only relatively recently changed environment in which the triumph of shareholder value maximization had become the norm, not the exception. Well into the 1960s, corporations - not only in Europe, but also in the United States - had been embedded in a tightly woven regulatory infrastructure that created a politically charged environment for 'private commercial activity'. $^{17}$

After the 'roaring 1990s' (J. Stiglitz) and an obsession with short term value creation over the span of the last two and a half decades, the financial crisis has put all this into a new light. But the amnesia is still there as if to show that there just is no learning from the past. While the forceful debate over convergence versus divergence of corporate governance models would be a rich reservoir of stored knowledge and insights into the different regulatory systems and company law cultures that will inevitably shape any regulatory response envisioned today, the present soul-searching is strangely disinterested in drawing on that background. Instead, the dominant concern seems to be to curb the 'excesses' and the 'failures' of the regulatory

${ }^{11}$ See eg A. Dhir 2006. 'Realigning the Corporate Building Blocks: Shareholder Proposals as a Vehicle for Achieving Corporate Social and Human Rights Accountability', American Business Law Journal 43 pp. 365

12 T. Baums 2001. 'Interview: Reforming German Corporate Governance: Inside a Law Making Process of a Very New Nature', German Law Journal 2: pp. at: http://www.germanlawjournal.com/past_issues.php?id=43

${ }^{13}$ W. W. Bratton 2002. 'Enron and the Dark Side of Shareholder Value', Tulane Law Review 76: pp. 1275-1361

${ }^{14}$ P. Kolla 2004. 'The Mannesmann Trial and the Role of the Courts', German Law Journal 5: pp. 829-847; S. Maier 2006. 'A Close Look at the Mannesmann Trial', German Law Journal 7: pp. 603-610; M. Höpner and G. Jackson 2001. 'Entsteht ein Markt für Unternehmenskontrolle? Der Fall Mannesmann', Leviathan pp. 544-563

${ }^{15}$ L. A. Bebchuk and J. Fried 2004. Pay Without Performance. The Unfulfilled Promise of Executive Compensation, Harvard University Press; G.-P. Calliess and P. Zumbansen 2010. Rough Consensus and Running Code: A Theory of Transnational Private Law, Hart Publishing, pp. 227-247

${ }^{16}$ P. A. Gourevitch 2003. 'The Politics of Corporate Governance Regulation', Yale Law Journal 112: pp. 1829-1880; P. A. Gourevitch and J. Shinn 2005. Political Power and Corporate Control. The New Global Politics of Corporate Governance, Princeton University Press; and the chapter by James Shinn - in this volume.

${ }^{17}$ R. B. Reich 2007. Supercapitalism. The Transformation of Business, Democracy, and Everyday Life, Vintage, ch. 1 
apparatus that is understood to have been at the root cause of the present calamities. There is considerable evidence that the currently explored and designed regulatory 'responses' are more geared towards the 'fixing' of the system that prevailed over the past thirty years rather than towards a fundamental revisiting of the - existing - comparative and historical evidence as to the complex nature of the business corporation, its regulatory environment and the historical record of its evolution. ${ }^{18}$

The present chapter argues against such an ahistoric approach. It furthermore points to the comparative and legal theoretical insights into differently evolving corporate governance regimes as a basis for a better understanding of the particular nature of regulating corporate activities today.

\section{Beyond Comparisons: The Emergence of Transnational Corporate GOVERNANCE}

While comparative corporate or, in the English usage, company law researchers have come a long way in illuminating the embedded nature of historically evolved, socio-economically shaped corporate governance models ${ }^{19}$, it seems as if - motivated by a cross-fertilization of different disciplinary approaches ${ }^{20}$ - scholars are now more than before engaged in both comparative and interdisciplinary studies of existing corporate governance regulations. This is surely one, but not the only important prerequisite for any study of corporate governance today. To the degree that corporate governance has become a multi-level regulatory laboratory, in which 'hard' law overlaps and intersects with 'soft' law in numerous, fast-evolving ways, a traditional approach to the study of corporate or company law as a relatively confined doctrinal area soon reaches its limits. The present context of public and private norm creating actors engaged in the formulation, implementation and enforcement of corporate governance

\footnotetext{
${ }^{18}$ Albeit, there are exceptions: K. W. Dam 2010. 'The Subprime Crisis and Financial Regulation: International and Comparative Perspectives', Chicago Journal of International Law 10: pp. 581-638
}

${ }^{19}$ See, for example, J. W. Cioffi 2000. 'State of the Art: A Review Essay on Comparative Corporate Governance: The State of the Art and Emerging Research', American Journal of Comparative Law 48: pp. 501; M. O'Sullivan 2003. 'The political economy of comparative corporate governance', Rev. Int'l Pol. Econ. 10: pp. 23-72; S. Deakin 2007. 'Reflexive Governance and European Company Law', CLPE Research Paper Series (http://www.comparativeresearch.net/papers.jsp) \& Cambridge Centre for Business Research, Working Paper No. 346 pp. http://www.cbr.cam.ac.uk/pdf/wp346.pdf; A. Rebérioux 2002. 'European Style of Corporate Governance at the Crossroads: The Role of Worker Involvement', Journal of Common Market Studies 40: pp. 111-134.

20 See eg the brillant study by L. Klöhn 2006. Kapitalmarkt, Spekulation und Behavioral Finance. Eine interdisziplinäre und vergleichende Analyse zum Fluch und Segen der Spekulation und ihrer Regulierung durch Markt und Recht, Duncker \& Humblot. 
norms illustrates the need to expand corporate law's analytical toolkit as well as to understand corporate governance regulation in a wider context of increasingly transnational market regulation. $^{21}$

Today's transnational corporate governance regulation is a product of fundamental transformations of regulatory instruments and institutions. As corporate law is being shaped by a complex mix of public, private, state- and non-state-based norms, principles and rules, generated, disseminated and monitored by a diverse set of actors ${ }^{22}$, a closer look at corporate governance offers two insights: one concerns the way in which the analysis of contemporary corporate governance regulation can help us assess the emerging, new framework within which corporate governance rules are evolving. Secondly, the way in which we begin to understand the emerging regulatory framework as an illustration of contemporary rule-making, the legal pluralist deconstruction of formal and informal legal orders can be seen in a new light. Building, on the one hand, on early legal-sociological work by Ehrlich ('living law' ${ }^{23}$ ) and Gurvitch ('social $\left(a w^{\prime 24}\right)$, this inquiry revisits the core question of any sociology of law, namely 'to investigate the correlations between law and other spheres of culture. ${ }^{25}$

For the purposes of this chapter, our focus will be on the tension between law and alternative modes of market regulation. Expanding the spectrum, on the other, with a view to "legal pluralism" ${ }^{26}$, contemporary assessments of 'hybrid legal spaces' ${ }^{27}$ that are not sufficiently

${ }^{21}$ Calliess \& Zumbansen 2010, note 15, ch. 4 "Transnational Corporate Governance”

${ }^{22}$ See, for example, the overview at www.ecgi.org, and www.transnationalcorporategovernance.net.

${ }^{23}$ E. Ehrlich 1962. Fundamental Principles of the Sociology of Law (orig. published in German as Grundlegung der Soziologie des Rechts, 1913), Russell \& Russell

${ }^{24}$ G. Gurvitch 1947. Sociology of Law (orig. published in French as Problèmes de la sociologie du droit), Routledge and Kegan Paul

${ }^{25}$ E. Ehrlich 1962. Fundamental Principles of the Sociology of Law (orig. published in German as Grundlegung der Soziologie des Rechts, 1913), Russell \& Russell, 486-506 "The Study of the living law"; G. Gurvitch 1947. Sociology of Law (orig. published in French as Problèmes de la sociologie du droit), Routledge and Kegan Paul; M. Rheinstein 1941. 'Review: Two Recent Books on Sociology of Law [reviewing Timasheff's 'Introduction' and Gurvitch's 'Elements']', Ethics 51: pp. 220-231, 221-2

${ }^{26}$ S. F. Moore 1973. 'Law and Social Change: the semi-autonomous field as an appropriate subject of study', Law \& Society Review 7: pp. 719-746; M. Galanter 1981. 'Justice in many rooms: Courts, Private Ordering and Indigenous Law', Journal of Legal Pluralism 19: pp. 1-47; S. Macaulay 1986. 'Private Government', in L. Lipson and S. Wheeler (eds), Law and the Social Sciences. Washington, Russell Sage, pp. 445-518; B. d. Sousa Santos 1987. 'Law: A Map of Misreading. Toward a Postmodern Conception of Law', Journal of Law \& Society 14: pp. 279; G. Teubner 1992. 'The Two Faces of Janus: Rethinking Legal Pluralism', Cardozo Law Review 13: pp. 1443-1462; G. Teubner 2004. 'Societal Constitutionalism: Alternatives to State-Centred Constitutional Theory?' in C. Joerges, I.-J. Sand and G. Teubner (eds), Constitutionalism and Transnational Governance. Oxford, UK/Portland, OR, Hart Publishing, pp. 3-28 
captured with references to local or national contexts, can help us better understand the distinctly transnational character of such regulatory regimes. The transnational lens allows us to study such regimes not as entirely detached from national political and legal orders, but as emerging out of and reaching beyond them. ${ }^{28}$ The transnational dimension of new actors and newly emerging forms of norms radicalizes their 'semi-autonomous' nature (S. F. Moore) in the following way: regulatory spaces are marked by a dynamic and often problematic instrumentalist tension between formal and informal norm-making processes, which cannot easily be subjected to a political critique because the co-existence of hard and soft laws does not necessarily or always reflect on a strategy of depoliticisation. Instead, the choice of different modes of regulations has its origin most frequently in a situation in which political disagreement is only one among several roadblocks for effective regulation or, legal reform. ${ }^{29}$ Other problems are likely to result out of complex constellations of different overlapping and colliding norm-making authorities, something that has been shaping regulation attempts in different transnational governance regimes, from securities regulation ${ }^{30}$, corporate governance, labour law $^{31}$, contract law in general $\left.\right|^{32}$ and consumer protection law in particular ${ }^{33}$ are

27 P. Schiff Berman 2007. 'Global Legal Pluralism', S. Cal. L. Rev. 80: pp. 1155-1237, 1155; see already S. Sassen 2006. Territory - Authority - Rights. From Medieval to Global Assemblages, Princeton University Press.

${ }^{28}$ For a discussion, see C. M. Scott 2009. "Transnational Law' as Proto-Concept: Three Conceptions', German Law Journal 10: pp. 859-876, and P. Zumbansen 2006. 'Transnational Law', in J. Smits (ed) Encyclopedia of Comparative Law. Edward Elgar, pp. 738-754.

${ }^{29}$ With regard to the example of co-determination, see eg J. N. Ziegler 2001. 'Corporate Governance in Germany: Toward a New Transnational Politics?' in S. Weber (ed) Globalization and the European political economy. New York, Columbia University Press, pp. 197-228, and K. Pistor 1999. 'Codetermination: A Sociopolitical Model with Governance Externalities', in M. Blair and M. J. Roe (eds), Employees and Corporate Governance. Washington, Brookings Institution, pp. 163-193.

30 J. Black and D. Rouch 2008. 'The development of global markets as rule-makers: engagement and legitimacy', Law and Financial Markets Review pp. 218-233; T. M. J. Möllers 2008. 'Europäische Methoden- und Gesetzgebungslehre im Kapitalmarktrecht. Vollharmonisierung, Generalklauseln und soft law im Rahmen des Lamfalussy-Verfahrens zur Etablierung von Standards', Zeitschrift für Europäisches Privatrecht pp. 480-505

${ }^{31}$ A. Supiot 1999. Au-delà de l'emploi. Transformation du travail et devenir du droit du travail en Europe. Rapport pour la Commission européenne., Flammarion; J. B. Atleson, L. Compa and K. Rittich 2008. International Labor Law: Cases and Materials on Workers' Rights in the Global Economy, Thomson West

32 J. Basedow 1996. 'A Common Contract Law for the Common Market', Common Market Law Review 33: pp. 11691195 
increasingly marked by the existence of opt-out clauses and self-regulation mechanisms rather than being defined by enforceable hard-law rules. The dynamic character of such transnational regulatory regimes poses distinct challenges for a political theory of market regulation, which seems to be at least one of the several goals pursued within the present crisis-response soulsearch. The framework for a distinctly political critique of crisis-response regulation is today anything but certain. As long been recognised, even with the goal of an internal market in view, any attempt at the harmonisation of norms and the institutionalisation of an administrative framework is inevitably confronted with the particular dynamics of historically grown national legal, political and political cultures and the still in many ways contested overarching economic and political project of the EU. The sobering critique of the allegedly unbearable costs of Europe's 'Social Model' ${ }^{34}$ only aggravate the already frustrating efforts of confronting the current disembeddedness of global markets, which is one of the most important underlying themes in today's critique of 'supercapitalism' ${ }^{35}$ and which received its most pertinent critique by Karl Polanyi in his 1944 treatise on 'The Great Transformation'.

\section{The Problem of DisembeddednesS}

In his famous chapters on 'Societies and Economic Systems' and the 'Evolution of the Market Pattern', which we today refer to for the concept of the embeddedness of the market, Polanyi noted, that 'though the institution of the market was fairly common since the later Stone Age, its role was no more than incidental to economic life. ${ }^{36} \mathrm{~A}$ little later, he remarked that the outstanding discovery of recent historical and anthropological research is that man's economy, as a rule, is submerged in his social relationships. [...] Neither the process of production nor that of distribution is linked to specific economic interests attached to the possession of goods; but every single step in that process is geared to a number of social interests which eventually will be very different in a small hunting or fishing community than those in a vast despotic society, but in either case the economic system will be run on non-economic motives. ${ }^{37}$

${ }^{33}$ G.-P. Calliess 2002. 'Reflexive Transnational Law. The Privatisation of Civil Law and the Civilisation of Private Law', Zeitschrift für Rechtssoziologie 23: pp. 185-216; G.-P. Calliess 2006. Grenzüberschreitende Verbraucherverträge. Rechtssicherheit und Gerechtigkeit auf dem elektronischen Weltmarktplatz, Mohr Siebeck

${ }^{34}$ THE ECONOMIST, 9 July 2010: “Can Anything Perk Up Europe?”

${ }^{35}$ R. B. Reich 2007. Supercapitalism. The Transformation of Business, Democracy, and Everyday Life, Vintage; see also Axel Haunschild, 'Contingent Work: The Problem of Disembeddedness and Economic Reembeddedness', Management Review, 1 January 2004, http://www.allbusiness.com/human-resources/careers/1078135-1.html

${ }^{36}$ Karl K. Polanyi 1944. The Great Transformation. The Political and Economic Origins of our Time, Beacon Press), p. 43; this passage is later complemented - in the same chapter - by his remarks about 'man as a social being' (ibid., p. 46): 'His natural endowments reappear with a remarkable constancy in societies of all times and places; and the necessary preconditions of the survival of human society appear to be immutably the same.'

${ }^{37}$ Polanyi, p. 46. 
As is well known, this chapter (4) concludes with the elaboration of the three famous marketstructuring and market-organising principles: 'reciprocity' (related to family and kinship), 'redistribution' (the central collection and dissemination of production - '... these functions of an economic system proper are completely absorbed by the intensively vivid experiences which offer superabundant non-economic motivation for every act performed in the frame of the social system as a whole.' (p. 48)), and 'householding' (oeconomia), which precedes the rising levels of division of labour, as well as the role of money and credit. Building on this taxonomy, Polanyi famously wrote that 'the control of the economic system by the market is of overwhelming consequence to the whole organization of society: it means no less than the running of society as an adjunct to the market. Instead of economy being embedded in social relations, social relations are embedded in the economic system. ${ }^{38}$

It is here, where, as under a magnifying glass, we not only find the kernel of the critique of capitalism unfolding in the latter half of the Twentieth century, ${ }^{39}$ but also a powerful illustration of the differentiation concept of contemporary modern sociology, most strikingly, the thesis of the hegemony of the economic system in a functionally-differentiated society. ${ }^{40}$ Again, in Polanyi's words: 'The vital importance of the economic factor to the existence of society precludes any other result. For once the economic system is organised in separate institutions, based on specific motives and conferring a special status, society must be shaped in such a manner as to allow that system to function according to its own laws. This is the meaning of the familiar assertion that a market economy can function only in market society. ${ }^{41} \mathrm{~A}$ little further on, Polanyi added a devastatingly prophetic observation of competitive markets and shorttermism by noting that 'with every step that the state took to rid the market of particularist restrictions, of tolls and prohibitions, it imperiled the organized system of production and distribution which was now threatened by unregulated competition and the intrusion of the interloper who 'scooped' the market but offered no guarantee of permanency. ${ }^{42}$

\footnotetext{
${ }^{38}$ Polanyi, p. 57.
}

${ }^{39}$ See, for example, J. Derrida 1994. Specters of Marx. The State of the Debt, the Work of Mourning and the New International, Routledge); R. Rorty 1998. Das kommunistische Manifest 150 Jahre danach, Suhrkamp).

${ }^{40}$ N. Luhmann 1988. Die Wirtschaft der Gesellschaft, Suhrkamp).

${ }^{41}$ Ibid.

${ }^{42}$ Polanyi, p. 66. 
But, in which way if at all can Polanyi help us think through the challenges of crisis-response market regulation? Can his observations offer analytical tools for an adequate explanation of contemporary markets? I want to suggest that we look for an answer through a detour. Using corporate governance and capital market regulation as an illustration of the evolution of transnational markets, we can canvass a number of theoretical approaches that directly or indirectly draw upon Polanyi's critique of dis-embeddedness. Even where contemporary regulators, policy-makers and EU law, company law and securities regulation scholars do not engage with Polanyi per se, the pertinence of his assessment of the transformation of states, societies and markets is, nevertheless, both evident and crucial for our assessment of the argumentative and conceptual context in which a re-formulation of Polanyi's embeddedness theme would have to take place.

As such, the following observations can be at best cursory comments on the evolving institutional and conceptual dimensions of 'market regulation' or 'state intervention' in the areas of capital market law and corporate governance. While, geographically, the chapter draws on examples from the EU, the concerned regulatory regimes can more adequately be understood as 'global assemblages' in the sense introduced by the sociologist Saskia Sassen. ${ }^{43}$ Building on her work, I understand these regulatory regimes as examples of transnational legal pluralism. ${ }^{44}$ They are, on the one hand, neither exclusively national (domestic) nor international, while, on the other, they are not meant to eliminate or to overcome the nation state. ${ }^{45}$ Instead, these assemblages are constituted through persistent local activity and interpretation, and are - as such - comprised of human, institutional and technological elements, the latter resulting pre-dominantly from the breathtaking advances in information technology ('digitalisations') ${ }^{46}$ and the extreme acceleration in information, knowledge and capital transfer they made available. It is the precarious relation between national and global governance regimes that speaks to the continuing need for a specifically legal perspective on the re-configuration of 'spaces and places', which Sassen depicts in her work. And it is this

\footnotetext{
${ }^{43}$ For this concept, see Sassen, above, note 27; for earlier elaborations, see idem, The Global City, (Princeton NJ: Princeton University Press, 1991), and idem, Globalization and Its Discontents. Essays on the New Mobility of People and Money, (New York: The New Press, 1998); see, also, M. Amstutz \& V. Karavas, 'Weltrecht: Ein Derridasches Monster', in: G.-P. Calliess, A. Fischer-Lescano, D. Wielsch \& P. Zumbansen, (eds), Soziologische Jurisprudenz. Liber Amicorum für Gunther Teubner zum 65. Geburtstag, (Berlin-New York: Walter de Gruyter, 2009), pp. 647-674.

44 P. Zumbansen, "New Governance' in European Corporate Governance Regulation as Transnational Legal Pluralism', (2008) 15 European Law Journal, pp. 246-276, available at: http://ssrn.com/abstract=1128145; P. Zumbansen, Transnational Legal Pluralism, (2010) 1:2 Transnational Legal Theory, available as CLPE Research Paper 01/2010, at: http://ssrn.com/abstract=1542907

${ }^{45}$ Sassen, 2006, note 27, p. 325.

${ }^{46}$ Sassen, 2006, p. 349 (noting the importance of focusing on financial centres, not 'markets', 'as key nested communities enabling the construction and functioning of such cultures of interpretation'.
} 
emphasis on the legal theoretical re-construction of Polanyi's theme of embeddedness that holds considerable promise for rendering a timely concept of transnational markets.

The remainder of the chapter is structured as follows: First, I will contrast the pursued regulatory strategies in the two areas of capital market law and corporate governance in the EU. The central assumption of this complementary presentation of these two areas, which have seen a surge in regulatory activity - in both Europe and beyond - is that, in particular, the transformation of corporate finance during the last two decades has led to a far-reaching approximation of both areas. This is a remarkable development, as it raises intriguing questions regarding, for one, the methodology that informs the conceptual construction and the demarcation of legal doctrinal fields. In other words, how and why do we (continue to) distinguish between capital market law and corporate governance (law)? Secondly, the apparent overlapping and inter-twining of these two distinct regulatory areas presents formidable challenges for our understanding of the law and the specific regulatory instruments which are relied upon to govern each or both of the areas concerned.

In the next section, I will reflect on the driving forces behind the continuing regulatory reform process in both areas and discuss recurring concepts such as 'maximum', 'minimum', or 'reflexive' harmonisation and regulatory competition against the analysis of Polanyi's market embeddedness and the work on the so-called 'Varieties of Capitalism' studies. ${ }^{47}$ The last section seeks to provide an explanation for the particular forms of legal regulatory regimes that are emerging in the named areas by elaborating the concept of transnational legal pluralism.

\section{CAPital Market Regulation and CoRporate Governance}

\section{A. In Search of A Harmonised European SeCurities Market}

We can here only provide a very abbreviated overview and assessment of the developments made with regard to the regulation of capital market law in recent times. One of the central insights one can gain from the fast evolving scholarly work in this area seems to be that longterm, economic growth in Europe is closely linked to an effectively and supportively regulated securities market. Namely, the European Commission and the European Court of Justice (ECJ) have been playing decisive roles in the context of shaping a continuously evolving, regulatory framework in this area. Central to the Commission's regulatory efforts was the 1999 release of

\footnotetext{
47 J.R. Hollingsworth, 'New perspectives on the spatial dimensions of economic coordination: tensions between globalization and social systems of production', (1998) 5 Review of International Political Economy, pp. 482-507; P.A. Hall \& D. Soskice (eds), Varieties of Capitalism. The Institutional Foundations of Comparative Advantage, (Oxford-New York, Oxford University Press, 2001).
} 
the Financial Services Action Plan (FASP), which spurred a tremendously dynamic series of legislative initiatives in its wake. The FASP came into being at a time when there was very little movement and even less advancement in the area of corporate law harmonisation - some even spoke of an 'almost empty' agenda. ${ }^{48}$ Programmatic and regulatory initiatives in the context of the FASP have included the inauguration of the Lamfalussy Commission, which, in 2001, after the release of a preliminary report and the initiation of a consultation process, produced its comprehensive final report, in which it addressed and discussed both the challenges and the needs to work towards an efficient and dynamic securities market in Europe. ${ }^{49}$ Echoing the views shared by a wide spectrum of scholars and practitioners in the field, the Report identified, from the outset, the immediate necessity to bring swift reform to the existing regulatory framework in European financial regulation. This reform had become necessary mainly in the light of the breathtaking advances made in financial activity around the world over the past 15-20 years, the consequences of which, for securities regulation on the one hand, and for corporate (organisation and finance) law on the other, were becoming increasingly obvious. ${ }^{50}$

Despite the fact that the FASP regulatory initiatives are characterised by a very recent history, the wide-ranging assessments of their structure, aspirations, their successes and their shortcomings are fast beginning to fill symposia, edited collections and bibliographies, not to mention the abundance of working papers appearing, in short succession, in the Social Science Research Network (www.ssrn.com). Central to the debates surrounding the state of the European Financial Market after the introduction of a number of Directives is the concern over the inconsistency of the implementation of the Directives on the part of the individual Member States. The verdict, for the time being at least, is that, due to the many political differences, on the one hand, and the existing variations of securities regulation institutions across Europe, on the other, a harmonised securities market is still a long way off. ${ }^{51}$ Examined closely, the Prospectus, ${ }^{52}$ Market Abuse, ${ }^{53}$ Takeover Bids ${ }^{54}$ and Transparency ${ }^{55}$ Directives and the Rating

${ }^{48}$ L. Enriques \& M. Gatti, 'EC Reforms of Corporate Governance and Capital Markets Law: Do They Tackle Insiders' Opportunism?', (2007) 28 Northwestern Journal of International Law and Business, pp. 1-33, at 4.

${ }^{49}$ For a chronology and related documents, go to: http://ec.europa.eu/internal market/securities/lamfalussy/index en.htm.

${ }^{50}$ See, for example, T.M.J. Möllers, 'Europäische Methoden- und Gesetzgebungslehre im Kapitalmarktrecht. Vollharmonisierung, Generalklauseln und soft law im Rahmen des Lamfalussy-Verfahrens zur Etablierung von Standards', (2008) Zeitschrift für Europäisches Privatrecht, pp. 480-505, at 482.

${ }^{51}$ See, only, L. Enriques \& M. Gatti, 'Is There a Uniform EU Securities Law After the Financial Services Action Plan?', (2007) Proceedings of the 7th Nordic Company Law Conference, available at: http://ssrn.com/abstract=982282.

${ }^{52}$ http://ec.europa.eu/internal market/securities/prospectus/index en.htm.

${ }^{53}$ http://ec.europa.eu/internal market/securities/abuse/index en.htm. 
Agencies Regulation ${ }^{56}$ allow a range of varying implementation regimes that are altogether committed to the idea of 'optionality', ${ }^{57}$ but, as a consequence, fall short of bringing about an effectively levelled playing-field for actors in the European Market. At the same time, the Lamfalussy Commission strengthened and formalised the operation of a monitoring mechanism, embodied by the European Securities Committee (ESC) on the one hand, and the Committee of European Securities Regulators (CESR) on the other. These committees play an important role in the evolving multi-polar and multi-level process of European securities regulation. ${ }^{58}$ After the political orientation has been identified through the Council and the Parliament, the Commission and the Parliament - in collaboration with the ESC and the CESR design the more concrete implementation and execution procedures. It is after this process that, in a third step, the CESR, through the different regulatory agencies that it brings together, produces recommendations and benchmark standards. Despite the fact that these recommendations and benchmarks are without legally-binding power, they are, nevertheless, meant to provide a compellingly coherent reference mark for the implementation of the measures introduced. In a fourth and final step, the Commission is in charge to assess whether the implementation of the regulations has been successful.

The particular dynamics of this regulatory area raise significant questions concerning the way in which legislative goals are being identified, which interests are being considered, and how these feed into both the constitution and the re-constitution of distinct doctrinal and conceptual fields. ${ }^{59}$ As in other areas, notably European Contract law and, more specifically,

\footnotetext{
${ }^{54}$ http://ec.europa.eu/internal market/company/takeoverbids/index en.htm.

${ }^{55}$ http://ec.europa.eu/internal market/securities/transparency/index en.htm.

${ }^{56}$ http://ec.europa.eu/internal market/securities/agencies/index en.htm

${ }^{57}$ For a conceptual discussion, see G. Hertig \& J.A. McCahery, 'An Agenda for Reform: Company and Takeover Law in Europe', in: G. Ferrarini, K.J. Hopt, J. Winter \& E. Wymeersch, (eds), Reforming Company and Takeover Law in Europe, (Oxford-New York: Oxford University Press, 2004), pp. 21-49.
}

58 T. M. J. Möllers 2010. 'Auf dem Weg zu einer neuen europäischen Finanzmarktaufsichtsstruktur - Ein systematischer Vergleich der Rating-VO (EG) Nr. 1060/2009 mit der geplanten ESMA-VO', Neue Zeitschrift für Gesellschaftsrecht pp. 285-290, 285, identifies six levels of capital market regulation now in existence (laws, regulation and, in the case of the German BaFin, soft laws, as well as framework directives, implementation directives recommendations/guidelines within the Lamfalussy process).

${ }^{59}$ See D. Alford 2006. 'The Lamfalussy Process and EU Bank Regulation: Another Step on the Road to Pan-European Regulation?' Annual Review of Banking \& Financial Law 25: pp. 389-441, 
European consumer protection law, ${ }^{60}$ the pursuit of a European regulatory framework in capital markets law and corporate governance occurs against highly-charged assessments of the underlying assumptions and goals that inform the regulatory process. In this context, market efficiency represents a highly persuasive formula which, when studied more closely, does not in itself - contain much clarification as to the interests and goals that are actually being pursued. This dilemma, which certainly seems to plague any reform agenda in complex regulatory areas, is further exacerbated by the fact that the European securities market (or, the European Company Law Scene ${ }^{61}$ ) constitutes an even more complex arena and context than a historically-evolved regulatory area in a particular state. ${ }^{62}$ As will be argued more fully below, substantive law reforms in Europe regularly occur against the backdrop of the open-ended European integration project.

Before we briefly highlight the particular dimensions of European Corporate Governance Regulation (ECGR), we shall pause for a moment to reflect upon the connections between capital market law and corporate governance. The different speeds at which each area has been developing in Europe could suggest that it would, indeed, be possible to distinguish neatly between them as clearly distinct, conceptually and doctrinally contained, regulatory areas. However, there are several elements at play, which point in the opposite direction, which we briefly want to allude to under the heading of the 'financialisation of the corporation'.

\section{B. THE FinANCIALISATION OF THE CORPORATION}

Since the 1965s, the transformation of the corporation has led to a widely-held acceptance of subjecting every element of a business firm to varied processes of financialisation, ${ }^{63}$ which was spurred by a number of path-breaking innovations in financial economics that eventually

${ }^{60}$ U. Mattei \& F. Nicola, 'A 'Social Dimension' in European Private Law? The Call for Setting a Progressive Agenda', (2006) 41 New England Law Review, pp. 1-66; G. Howells \& T. Wilhelmsson, 'EC Consumer Law: Has it Come of Age?', (2003) 28 European Law Review, pp. 370-388;G.-P. Calliess, 'The Limits of Eclecticism in Consumer Law: National Struggles and the Hope for a coherent European Contract Law: A Comment on the ECJ's and the FCJ's 'Heininger' Decisions', (2002) 3 German Law Journal, available at: http://www.germanlawjournal.com/past issues.php?id=175.

${ }^{61}$ C.M. Schmitthoff, 'The Future of the European Company Law Scene', in: idem, (ed), The Harmonisation of European Company Law, (London: The U.K. National Committee of Comparative Law, 1973), pp. 3-27.

${ }^{62}$ For an illustration of the latter, see R. Romano, The Genius of American Corporate Law, (Washington DC: The American Enterprise Institute Press, 1993); for the former, see R. Buxbaum \& K.J. Hopt, Legal Harmonization and the Business Enterprise. Corporate and Capital Market Law Harmonization Policy in Europe and the U.S.A, (BerlinNew York: Walter de Gruyter, 1988).

${ }^{63}$ R. Dore, 'Financialization of the Global Economy', (2008) 17 Industrial and Corporate Change, pp. 1097-1112, at 1099: 'The basic financial innovation on which the pyramid of ever more arcane financial instruments is built is securitization.' 
prepared the ground for a new 'theory of the firm' ${ }^{64}$ and was over time complemented by a fast proliferating landscape of investment actors. ${ }^{65}$ This transformation affected corporations throughout the world and was driven by the attempt to effectively attract a highly diversified investment of global investment pools. Far-reaching de-regulation with regard to capital control during the 1980s facilitated an unprecedented flow of capital across national boundaries, which permitted securitisations, often repeatedly, of a large number of assets, including pension schemes, real estate and commercial claims. With companies designing corporate strategies primarily with stock performance in mind, shareholder value became the dominating principle in assessing corporate performance, fuelled by a seemingly unstoppable growth in index values.

The focus on the short-term volatility of corporate shares in order to evaluate a company's merits and prospects quickly became the only perspective from which we claimed to understand a firm. ${ }^{66}$ But this narrowing of the field of vision came at a price, as both investors and managers became blind to the fact that the very environment of firms had been dramatically transformed over the course of a few decades. To the degree that the advancement of communication and information technology revolutionised the transfer of derivatives - sometimes as a company's virtual assets - across vast strategic spaces, the attention given to stock performance eventually removed the firm from its geographical environment by elevating it into a purely ethereal realm. In consequence of its financialisation, the share or other security of the corporation (its 'reference asset' for the creation of another synthetic security) became radically virtualised. What architects of synthetic credit instruments call the reference asset, which can be the original subject of a loan or security, became radically virtualised in relation to the business corporation. The corporation, in turn, was reduced to an anchoring point for independently originated financial programmes, thereby positioning the corporation no longer in a real economy, but in an artificial space of financial engineering.

In the end, the firm - as we have come to understand it over the past thirty years - had even outgrown even the ideal model of a nexus of contracts. ${ }^{67}$ In order to remain operational, the

64 A. A. Alchian and H. Demsetz 1972. 'Production, Information Costs, and Economic Organization', American Economic Review 62: pp. 777-795; M. C. Jensen 2000. A Theory of the Firm. Governance, Residual Claims, and Organizational Forms, Harvard University Press

${ }^{65}$ F. Partnoy \& R. Thomas. 'Gap Filling, Hedge Funds and Financial Innovation', in: Y. Fuchita \& R.E. Litan (eds), New Financial Instruments and Institutions. Opportunities and Policy Challenges, (Washington DC: Brookings Institution, 2007), pp. 101-140.

${ }^{66}$ W. Lazonick \& M. O'Sullivan, 'Maximizing Shareholder Value: A New Ideology for Corporate Governance', in: idem, (eds), Corporate Governance and Sustainable Prosperity, (London: Palgrave Macmillan, 2002), pp. 11-36.

67 A.A. Alchian \& H. Demsetz, 'Production, Information Costs, and Economic Organization', (1972) 62 American Economic Review, pp. 777-795;M.C. Jensen, A Theory of the Firm. Governance, Residual Claims, and Organizational Forms, (Cambridge MA-London: Harvard University Press, 2000). 
model had to be adapted to the processes of financial engineering, which - at least partially moved the corporation out of the centre of the labyrinth of contracts in which it was, or its securities were, entangled. The financialisation of the corporation and its securities entailed a radical separation of the corporation, itself, from the instruments that represent claims in, of, or against, the corporation. The corporation had become a nodal point for an ephemeral crossing, the inter-linking and overlapping of financial vectors, channelled through the glass structure of the legal person, with almost no relationship with the original 'business' of the corporation. A dream fulfilled, with money flowing in and out of the firm, the corporation had become a virtual realm for strategic investment.

The financialisation of corporate governance is powerfully reflected in the fast rise in importance of financial experts on the boards of directors, the importance of financial expertise in the making of business decisions and, finally, in the transformation of the educational environment for the supporting professions - including lawyers, consultancies and accountants. The flip-side of this is the dramatic erosion of the representation of labour interests in the contemporary business corporation. ${ }^{68}$ Where corporate activity had, for a long time, been marked by a lively public political discussion of the interests of the different constituencies in the firm, its financial and physical virtualisation ${ }^{69}$ increasingly erased the reference points for a general assessment of what corporations were actually doing.

As suggested above, the financialisation of the corporation led to significant changes in the corporate regulatory framework. The financialisation of the business corporation, which, arguably, had always been part of the corporate identity, ${ }^{70}$ does not, however, exhaust itself, neither in the adaptation of corporate finance to the globally available, highly-diversified investment tools and opportunities, nor in the wide-ranging turn of regulatory policy towards shareholder value, which gave rise to the 'corporate governance movement' of the last decade in both corporate law theory and practice. Moreover, the financialisation paradigm eventually led to a dramatic re-configuration of the "embedded corporation" ${ }^{71}$ by upsetting and shifting

\footnotetext{
${ }^{68}$ S. Deakin 2010. 'Corporate Governance and Financial Crisis in the Long Run', in P. Zumbansen and C. A. Williams (eds), The Embedded Firm: Corporate Governance, Labour and Financial Capitalism. Cambridge, UK, Cambridge University Press, pp. forthcoming
}

${ }^{69}$ See, for example, W.H. Davidow \& M.S. Malone, The Virtual Corporation. Structuring and Revitalizing the Corporation for the 21st Century, (New York: Harper Collins, 1992); for the foundations, see M. Castells, The Rise of the Network Society, The Information Age: Economy, Society and Culture, Vol. I. (2nd ed., 2000) (Cambridge MA-Oxford: Blackwell Publishing, 1996).

70 L.E. Mitchell, The Speculation Economy. How Finance Triumphed over Industry, (San Francisco CA: BerrettKoehler Publishers, 2007).

${ }^{71}$ S.M. Jacoby, The Embedded Corporation. Corporate Governance and Employment Relations in Japan and the United States, (Princeton NJ-Oxford: Princeton University Press, 2004). 
the institutional framework of the corporation's regulatory environment, ${ }^{72}$ with tremendous consequences at both the domestic and the transnational level. As national governments found themselves drawn into highly-charged political debates regarding the goals of company law reform, which were themselves increasingly likened to existential questions of national survival, ${ }^{73}$ the European law-maker, too, came under growing pressure to follow up on longstanding promises and aspirations to work towards a more effective level playing-field for European companies.

\section{The Turns of European Corporate Governance}

Against this background, it is unsurprising that the history of European corporate law regulation is marked by the diversity of the interests and concerns invested in this area of regulation. While the legislative record was, until recently, not altogether comprehensive ${ }^{74}$ the ECGR has, in the last years, become one of the most vibrant sectors of norm-creation and regulatory interaction. As such, the ECGR has become a regulatory universe of its own, with a large portfolio within the Commission's Internal Market division, and a seemingly tireless expert community feeding into the policy-making and norm-making processes at every turn. With the ECGR long having left the confines of the European Court of Justice, the Council and the Parliament, it has expanded into an extremely versatile, comparative and transnational legal field. The ECGR constitutes a semi-autonomous field, comprised both of hard law and social norms, which are in a constant relationship of complementarity, fusion and irritation. ${ }^{75}$ As such, the ECGR presents formidable challenges for legal, economic, sociological or political analysis. From the point of view of legal pluralism, the particularity and the intricacy of the ECGR lies in

72 J. Hoffmann, 'Co-ordinated Continental European Market Economies Under Pressure From Globalisation: Germany's 'Rhineland capitalism” (2004) 5 German Law Journal, pp. 985-1002; J.W. Cioffi, 'Corporate Governance Reform, Regulatory Politics, and the Foundations of Finance Capitalism in the United States and Germany', (2006) 7 German Law Journal, pp. 533-562.

${ }^{73}$ T. Baums, 'Interview: Reforming German Corporate Governance: Inside a Law Making Process of a Very New Nature', (2001) 2 German Law Journal, available at: http://www.germanlawjournal.com/past issues.php?id=43

74 J. Wouters, 'European Company Law: Quo Vadis?', (2000) 37 Common Market Law Review, pp. 257-307; V. Edwards, EC Company Law, (Oxford-New York: Oxford University Press, 1999); K.J. Hopt. 'European Company Law and Corporate Governance: Where does the Action Plan of the European Commission Lead?', in: K.J. Hopt, E. Wymeersch, H. Kanda \& H. Baum (eds), Corporate Governance in Context, (Oxford-New York: Oxford University Press, 2005), pp. 119-142.

${ }^{75}$ S.F. Moore, 'Law and Social Change: the semi-autonomous field as an appropriate subject of study', (1973) 7 Law \& Society Review, pp. 719-746. 
its mixed constitution of law and 'social norms' ${ }^{76}$ Seen through the legal pluralist lens, the ECGR develops as a co-evolutionary process, in which the imposition of law - which encompasses regulations, directives, recommendations and judgments - is both shaping and being shaped by the norms evolving outside of its imposition. Similar to the unpredictability of the consequences and the effects of rights/principles-transplants, ${ }^{77}$ the ECGR faces enormous challenges in terms of both legal certainty and strategy, given its many sources of potential disturbance, irritation, and complementing points, due to its complex regulatory agenda.

Adding to the difficulties arising from the multilevel and multi-stakeholder dimension in company law regulation in Europe, the ECGR has amplified the tensions that underlie the conceptual and architectural distinction between 'company' and 'capital market' law, which are deeply embedded in a country's market regulation history. ${ }^{78}$ Struggling with competing policy goals regarding the enhancement of market freedoms as they relate to capital market rules, on the one hand, and to corporate governance law, on the other, the ECGR is driven to actualise 'the best of both worlds'. However, while corporate law, itself, appears to continue to withstand all attempts at de-construction and de-mystification by other conceptual frameworks with regard to what corporations actually do, ${ }^{79}$ the ECGR finds itself deeply involved in a large, ever-so amorphous market-building project. The understanding of the 'function' of the firm, as it informs ECGR, must now extend far beyond the financial-organisational dimensions that became the 'what', 'how' and 'why' of corporate law. Within the European project, in particular after the Lisbon Summit 2000 and its more recent re-invigoration in the form of a 'social makeover', ${ }^{80}$ corporate law has become a strategic token in a complex multilevel governance

${ }^{76}$ See, generally, S.E. Merry, 'Legal Pluralism', (1988) 22 Law \& Society Review, pp. 869-901.

${ }^{77}$ G. Teubner, 'Legal Irritants: How Unifying Law Ends Up In New Divergences', in: P.A. Hall \& D. Soskice (eds), Varieties of Capitalism. The Institutional Foundations of Comparative Advantage, (Oxford-New York: Oxford University Press, 2001), pp. 417-441; K. Pistor, 'Of Legal Transplants, Legal Irritants, and Economic Development', in: P. Cornelius \& B. Kogut (eds), Corporate Governance and Capital Flows in a Global Economy, (Oxford-New York: Oxford University Press, 2003), pp. 347-366.

${ }^{78}$ R. Wiethölter, Interessen und Organisation der Aktiengesellschaft im amerikanischen und deutschen Recht, (Karlsruhe: C.F. Müller, 1961); Buxbaum \& Hopt 1988; F. Kübler, 'The Impact of Equity Markets on Business Organization: Some Comparative Observations Regarding Differences in the Evolution of Corporate Structures', (2001) 2 European Business Organization Law Review, pp. 669-683; H. Merkt, 'Zum Verhältnis von Kapitalmarktrecht und Gesellschaftsrecht in der Diskussion um die Corporate Governance', (2003) 48 Die Aktiengesellschaft, pp. 126-136; H. Eidenmüller, 'Forschungsperspektiven im Unternehmensrecht', (2007) 62 Juristenzeitung, pp. 487-494;N. Moloney, 'New Frontiers in EC Capital Markets Law: From Market Construction to Market Regulation', (2003) 40 Common Market Law Review, pp. 809-843; for the U.S., see, only,R. Romano, 'The Sarbanes-Oxley Act and the Making of Quack Corporate Governance', (2005) 114 Yale Law Journal, pp. 1521-1611

${ }^{79}$ See, only, R.C. Clark, Corporate Law, (Boston MA: Brown \& Little, 1986).

${ }^{80}$ http://www.euractiv.com/en/innovation/eu-lisbon-agenda-gets-social-makeover/article-171013. 
game that brings a much wider range of players to the policy-making table than any singlemarket regulation unit would reasonably want to assume responsibility for.

The ECGR, driven by pressing competitive, social, environmental and monitoring demands, continues to evolve in the particularly accentuated and contested space of the competitiveness agendas of the EU Member States. As such, the ECGR has never sat comfortably within the wider market integration agenda. The real challenges of company law harmonisation, however, became impressively obvious during the exhausting struggle over the adoption of a regulation concerning the creation of the European Company statute, originally initiated in the 1970s, and eventually passed after many more compromises, in 2001. Another illustration of how the ECGR has been inextricably caught up in the European 'Varieties of Capitalism' was, without doubt, the long contest over a European Takeover Directive, which resulted, in 2004, in a Directive full of loopholes and opt-out clauses. ${ }^{81}$

As the regulatory trajectory of the ECGR continues to unfold, we must be even more sensitive to the degree to which this enterprise remains deeply embedded in the particular dynamics of the multilevel governance of European integration, on the one hand, ${ }^{82}$ and the globalisation of markets and regulatory processes, on the other. ${ }^{83}$ Under such conditions, an assessment of the concrete forms of norm-creation presents great challenges due to the ECGR's complex appearance, which ranges from 'hard' to 'soft' law, to norms that are developed, promulgated and disseminated by a panoply of public and private actors. ${ }^{84}$ Thus, instead of trying to free the

${ }^{81}$ C. Kirchner \& R.W. Painter, 'Takeover Defenses under Delaware Law, the Proposed Thirteenth EU Directive and the New German Takeover Law: Comparison and Recommendations for Reform', (2002) 50 American Journal of Comparative Law, pp. 451-476; B. Clarke, 'The EU Takeovers Directive: A Shareholder or stakeholder model?', in: P. Zumbansen \& C.A. Williams (eds), The Embedded Firm: Labour, Corporate Governance and Finance Capitalism, (2010), pp. forthcoming; see, also, J. Armour \& D. Skeel Jr., 'Who Writes the Rules for Hostile Takeovers, and Why?-The Peculiar Divergence of U.S. and U.K. Takeover Regulation', (2007) 95 Georgetown Law Journal, pp. 1727-1794; for a comprehensive analysis of the Directive in the context of EU corporate governance regulation, see B. Sjåfjell, 'Political Path Dependency in Practice: the Takeover Directive', (2009) 27 Yearbook of European Law, pp. 387-404, and idem, B. Sjåfjell, 'The Core of Corporate Governance: Implications of the Takeover Directive for Corporate Governance in Europe', (2009) Presentation at the 13th Irish European Law Forum, Dublin 4 December 2009, manuscript on file with author.

${ }^{82}$ C.F. Sabel \& J. Zeitlin, 'Learning from Difference: The New Architecture of Experimentalist Governance in the EU', (2008) 14 European Law Journal, pp. 271-327.

83 See, for example, D. Rodrik, 'Governance of Economic Globalization', in: J.S. Nye \& J. D. Donahue (eds), Governance in a Globalizing World, (Washington DC: Brookings Institute, 2000), pp. 347-365.

84 Ch. Joerges \& J. Neyer, 'From Intergovernmental Bargaining to Deliberative Political Processes: The Constitutionalisation of Comitology', (1997) 3 European Law Journal, pp. 273-299; D. Trubek \& L.G. Trubek, 'Hard 
ECGR from its embeddedness in this complex regulatory environment, the emphasis must be on the exact opposite. It is precisely by embracing the embeddedness of the ECGR as a transnational legal field that we can begin to see the concrete, as well as the amorphous, forms of change more clearly. Embeddedness, here, is understood in the following four dimensions:

1. The ECGR is informed by the policy and legislative dynamics between corporate law and capital-market law (securities regulation) as well as between corporate law and labour law, which are categorisations of functionally separable legal areas that can be found in all advanced industrialised societies and which are increasingly challenged through the global forces of rule-making;

2. The ECGR is entangled in the European 'Varieties of Capitalism' with regard to corporate and labour regulation, as evidenced, for example, in the struggle over the Takeover Directive and the statute of the Societas Europaea;

3. The ECGR is part of the larger project which aims towards the completion of the European internal market, ${ }^{85}$ in particular, in the post-Lisbon environment of knowledge society politics within the EU; ${ }^{86}$

4. The ECGR is a semi-autonomous field, which is both vibrant and precarious, and is always threatened by the balance between official law-making, transnational consultations, expert committee preparatory work, recommendations, communications and standardisation, which we see unfolding at domestic, EU-supranational and transnational levels.

In Europe, the turn to 'law and finance' is occurring very persuasively, ${ }^{87}$ and with consequences for the continuously evolving regulatory landscape. As the European Commission continues to pursue a very effective dual agenda of revising and expanding the reach of capital market law Directives, on the one hand, and on indirectly reforming company law rules, on the other, we find a powerful illustration of the emerging culture of interpretation. Making the 'European Company Law Scene' one of the most vibrant law-making and norm-making markets

and Soft Law in the Construction of Social Europe: the Role of the Open Method of Coordination', (2005) 11 European Law Journal, pp. 343-364.

${ }^{85}$ C. Barnard and S. Deakin 2002. 'Market Access and Regulatory Competition', in C. Barnard and J. Scott (eds), The Law of the Single European Market. Unpacking the Premises. Oxford/Portland, OR, Hart Publishing, pp. 197-224 C. Barnard \& S. Deakin, 'Market Access and Regulatory Competition', in: C. Barnard \& J. Scott (eds), The Law of the Single European Market. Unpacking the Premises, (Oxford-Portland OR: Hart Publishing, 2002), pp. 197-224.

\footnotetext{
${ }^{86}$ See the Presidency Conclusions of the Council of the European Union [7652/08], March 13-14, 2008, available at: http://www.consilium.europa.eu/ueDocs/cms_Data/docs/pressData/en/ec/99410.pdf, p. 4: 'The implementation of the broad-based innovation strategy is key to realising EU ambitions in the area.' See, also, D. Pestre, 'Science, Society and Politics. Knowledge Societies from Historical Perspective', (2007) Report to the Science, Economy and Society Directorate at the European Commission, available at: http://ec.europa.eu/research/sciencesociety/document_library/pdf_06/historical-perspectives_en.pdf.
}

${ }^{87}$ B. Haar, 'Law and Finance - Kapitalmarktentwicklung in interdisziplinärer Perspektive', (2008) 63 Juristenzeitung, pp. 964-974; H. Fleischer, 'Zur Zukunft der gesellschafts- und kapitalmarktrechtlichen Forschung', (2007) Zeitschrift für Unternehmens- und Gesellschaftsrecht, pp. 500-510. 
worldwide, ${ }^{88}$ the European Commission has pursued one of the most sophisticated strategies of indirect, soft-law-making by delegating far-reaching bench-marking and best-practice formulation authorities to expert committees, on whose work the Commission has since issued far-reaching recommendations which, more often than not, have been the preparation for Directives. ${ }^{89}$

These ECGR developments thus represent a series of highly diversified norm-setting processes which have resulted in a veritable explosion of corporate governance codes in Europe and elsewhere. ${ }^{90}$ With the proliferation of corporate governance codes, influenced and driven by the international ${ }^{91}$ and transnational activities of norm-setting, discussion and thought exchange, ${ }^{92}$ it has become increasingly difficult to identify a single institution or author of a set of norms. Instead, the production and dissemination of corporate governance rules has, for some time now, taken on the nature of migrating standards, and a cross-fertilisation of norms is now regarded as both eminent and necessary in shaping future corporate activity. A distinct feature of this de-territorialised production of norms is the radical challenge that these processes pose for our understanding of what we call law proper. With the dissemination of corporate governance codes, disclosure standards and rules, best practices and codes of conduct, not only corporate and securities law, but also other fields of law - such as labour and employment law - change. It is this strangely amorphous space, which, due to its intricate relation to concrete places such as nation states, spheres of political decision making, of protest and so on, creates a dramatic challenge for attempts to foster the institutional conditions for public policy debates.

Loyal to the new institutional economists' reading, this liquidification of institutions constituted by the de-centralisation of norm producers is repeated, mirrored and reflected in the hybridisation of the norms themselves. Everything can become an 'institution', from a fully-

${ }^{88}$ E. Wymeersch, 'Convergence or Divergence in Corporate Governance Patterns in Western Europe?', in: J.A. McCahery, P. Moerland, T. Raaijmakers \& L. Renneborg, (eds), Corporate Governance Regimes. Convergence and Diversity, (Oxford-New York: Oxford University Press, 2002), pp. 230-247; L. Enriques \& P. Volpin, 'Corporate Governance Reforms in Continental Europe', (2007) 21 Journal of Economic Perspectives, pp. 117-140.

${ }^{89}$ G. Hertig \& J.A. McCahery, 'Optional rather than Mandatory EU Company Law: Framework and Specific Proposals', (2007) European Company and Financial Law Review, pp. 341-362.

${ }^{90}$ www.ecgi.org.

${ }^{91}$ OECD; WCFCG; IVCGN, etc.

${ }^{92}$ ECGI, INSEAD, Euroshareholders, etc. 
fledged regulatory apparatus to a handshake among business partners. It is in this sense that the study of the proliferation of corporate governance codes and company law production in general, and of the rules of remuneration disclosure in particular, feeds into a broader research into the changing face of legal regulation in globally-integrated market-places, which themselves become representations of society - which is precisely the nightmare that Polanyi so aptly depicted. ${ }^{93}$ What shines through the particular developments in individual jurisdictions in this regard is a most poignant exhibition of particular legal and political cultures and political economies of law-making and economic regulation. ${ }^{94}$

\section{The Ephemeral ‘Double Movement’ In the ECMR and the ECGR}

As has become clear, the evolution of European capital market law and corporate governance harmonisation not only offers itself as a case in point for the intricate process of European integration, but also serves to illustrate the nature of legal evolution as reflected in the increasingly multilevel and trans-territorialised norm production in the law of corporate governance. On the one hand, business has, for a long time now, come to be organised in a globe-spanning manner, with historically strong attempts to liberate itself of the regulatory aspirations or constraints of nation states. ${ }^{95}$ This is part of the nation state's larger struggle over regulatory sovereignty with regard to the economic processes that unfold both within and beyond national borders. On the other hand, however, corporations remain, in many respects, embedded in a complex field of historically grown, institutionally and legally structured frameworks of national regulation and administration. ${ }^{96}$ And, because national corporate laws are embedded in such distinct socio-economic cultures, and in historically-grown legal and industrial regimes, scholars in comparative corporate governance have become increasingly aware of the methodological challenges in comparing different corporate governance

\footnotetext{
${ }^{93}$ K. Polanyi 1944. The Great Transformation. The Political and Economic Origins of our Time, Beacon Press p. 57.

${ }^{94}$ P. Zumbansen, 'Spaces and Places: A Systems Theory Approach to Regulatory Competition in European Company Law', (2006) 12 European Law Journal, pp. 534-556.
}

95 C.M. Schmitthoff, 'International Business Law: A New Law Merchant', (1961) 2 Current Law and Social Problems, pp. 129-153; J.-P. Robé, 'Multinational Enterprises: The Constitution of a Pluralistic Legal Order', in: G. Teubner, (ed), Global Law Without A State, (Aldershot: Ashgate Publishing, 1997), pp. 45-77.

${ }^{96}$ M. O'Sullivan: 'Corporate Governance and Globalization', (2000) 570 The Annals of The American Academy of Political and Social Science [ANNALS], pp. 153-172; that 'culture' matters greatly, has been acknowledged widely; see, only, B.R. Cheffins, 'Putting Britain on the Roe Map: The Emergence of the Berle-Means Corporation in the United Kingdom', in: J.A. McCahery, P. Moerland, T. Raaijmakers \& L. Renneborg, (eds), Corporate Governance Regimes. Convergence and Diversity, (Oxford-New York: Oxford University Press, 2002), pp. 147-172; Buxbaum \& Hopt 1988; K J. Hopt, 'Common Principles of Corporate Governance in Europe?', in: J.A. McCahery, P. Moerland, T. Raaijmakers \& L. Renneborg (eds), Corporate Governance Regimes. Convergence and Diversity, (Oxford-New York: Oxford University Press, 2002), pp. 175-204; Á.R. Oquendo, 'Breaking on Through to the Other Side: Understanding European Corporate Governance', (2001) 22 University of Pennsylvania Journal of International Economic Law, pp. 975-1027, p. 976. 
regimes. ${ }^{97}$ After early critiques of a functional approach to comparative law ${ }^{98}$ had contributed to comparative legal scholarship's becoming much more nuanced, contextualised, and differentiated ${ }^{99}$ contemporary scholars place great emphasis upon the particular cultures of corporate governance norms, the role of institutions, policies, path dependency, and innovation. ${ }^{100}$ James Fanto astutely observed that '[c]orporate governance practices are partly cultural and historical products. In this context, culture can be defined as the conceptual framework whereby individuals, generally of the same country, understand and mediate the pressures of the world and motivate as well as explain their actions. As the corporation is a meaningful and purposeful human response to economic and social pressures, culture clearly informs corporate governance practices. ${ }^{101}$

Indeed, the considerably short history of European company and capital market law regulation provides numerous illustrations of this observation. There can be no doubt that there has been a strong push for streamlining in various areas of both company law and securities regulation, with changes having been initiated in particular by increased demands for transparency and more efficient management control. ${ }^{102}$ Yet, despite these developments, from a comparative viewpoint, company law has been considerably less amenable to radical reform than securities

97 D.C. Donald, 'Approaching Comparative Company Law', (2008) 14 Fordham Journal of Corporate and Financial Law, pp. 83-178; K.J. Hopt, 'Comparative Company Law', in: M. Reimann \& R. Zimmermann (eds), Oxford Handbook of Comparative Law, (Oxford-New York: Oxford University Press, 2006), pp. 1161-1191.

${ }^{98}$ J. Hill, 'Comparative Law, Law Reform and Legal Theory', (1989) 9 Oxford Journal of Legal Studies, pp. 101-115.

${ }^{99}$ See, for example, the helpful study by W.W. Bratton \& J.A. McCahery. 'Comparative Corporate Governance and Barriers to Global Cross Reference', in: J.A. McCahery et al., P. Moerland, T. Raaijmakers \& L. Renneborg, (eds), Corporate Governance Regimes. Convergence and Diversity, (Oxford-New York: Oxford University Press, 2002), pp. 23-55.

${ }^{100}$ See, foremost, M.J. Roe, 'Path Dependence, Political Options and Governance Systems', in: K.J. Hopt \& E. Wymeersch (eds), Comparative Corporate Governance. Essays and Materials, (Berlin-New York: Walter de Gruyter, 1997), pp. 165-184.

101 J. Fanto, 'The Role of Corporate Law in French Corporate Governance', (1998) 31 Cornell International Law Journal, pp. 31-91, at 36.

102 H. Davies \& D. Green, Global Financial Regulation. The Essential Guide, (Cambridge-Malden MA: Polity Press, 2008), p. 127; Enriques \& Gatti, note 48, above, p. 2. 
regulation, ${ }^{103}$ and even here the road towards a fully harmonised securities market is not a straight or easy one. ${ }^{104}$ European company law reflects the persisting challenges to European integration in that it highlights the difficulties of creating a body of law for social actors who have been relying on national rules, institutions, and customs within the nation state. ${ }^{105}$ This process has consistently highlighted the immense political and socio-economic obstacles emerging from the different 'varieties' and 'models' of capitalism of the different Member States, ${ }^{106}$ which are often associated with the substantive costs in bringing about an effective regulatory regime for companies operating and investing on the European market. ${ }^{107}$

Any attempt, therefore, at assessing and evaluating the regulatory goals as well as the prospects of the pursued ECGR and capital market law agendas needs to recognise the degree to which such rules are being developed in, and emerging from, a multilevel process of normproduction. With this, a study of European company law necessarily has to take into consideration not only the impact of different localities and the types of norm-production emerging in European-wide rules and standards, but also the persisting patterns of political opposition to reform. ${ }^{108}$ The German rules governing worker participation in business corporations remain, in this respect, a notorious example of a regime deeply embedded in the

${ }^{103}$ L. Enriques, 'Company Law Harmonization Reconsidered: What Role for the EC?', (2005) ECGI Law Working Paper No. 53/2005 (November), available at: http://ssrn.com/abstract=850005; Hertig \& McCahery 2004, note 57, p. 24; Hopt, 2002, note 96; Rebérioux, note 19.

${ }^{104}$ Enriques \& Gatti, note 48

105 See, only, F. Kübler, 'The Rules of Capital Under Pressure of the Securities Markets', in: K.J. Hopt \& E. Wymeersch (eds), Capital Markets and Company Law, (Oxford-New York: Oxford University Press, 2003), pp. 95114, at 100-101; N. Reich, Understanding EU Law. Objectives, Principles and Methods of Community Law, (2nd ed.) (Antwerp-Oxford: Intersentia, 2005), p. 349; S. Deakin, 'Reflexive Governance and European Company Law, in: CLPE Research Paper Series 2007', available at: $\quad$ www.comparativeresearch.net.

106 J.S. Knudsen, 'Is the Single Market an Illusion? Obstacles to Reform of EU Takeover Regulation', (2005) 11 European Law Journal, pp. 507-524, 524; see, already, M. Rhodes \& B. van Apeldoorn, 'Capital Unbound? The Transformation of European corporate governance', (1998) 5 Journal of European Public Policy, pp. $406-427$.

107 G. Hertig, 'Western Europe's Corporate Governance Dilemma', in: T. Baums, K.J. Hopt \& N. Horn (eds), Corporations, Capital Markets and Business in the Law. Liber Amicorum Richard M. Buxbaum, (London et al.: Kluwer Law International, 2000), pp. 265-282; Hertig \& McCahery, note 57, 2004, pp. 39-40; F. Kübler, 2003, note 105, pp. 101-103; Enriques 2005, note 103, pp.16-22.

108 Hertig \& McCahery, 2004, note 57 above, p. 24; E. Wymeersch, 'About Techniques of Regulating Companies in the European Union', in: G. Ferrarini, K.J. Hopt, J. Winter \& E. Wymeersch (eds), Reforming Company and Takeover Law in Europe, (Oxford-New York: Oxford University Press, 2004), pp. 145-182. 
country's political economy ${ }^{109}$ To touch upon one part of the legal framework would be likely to result in turmoil which would involve numerous other norms and institutions governing codetermination. ${ }^{110}$ Likewise, the long and painful struggle over a European takeover regime clearly reflected the complexities of a regulatory, socio-economic minefield, made up of cultural pre-dispositions, institutional traditions $\left(\right.$ Volkswagen $\left.^{111}\right)$ and established networks - all of which make any capital market law-oriented reformer frown, at the very least. ${ }^{112}$

\section{The Multifaceted Regulatory FramewORK Of CoRPorate Governance: POLANYI AND BEYOND}

\section{A. The Call for a New Corporate Governance}

Where does this leave us? Enriching the classical, formal-functionalist scope of comparative law in the past, scholars in law, economics, sociology and political science have, over the last twenty years, been developing an arguably more interdisciplinary and considerably richer perspective in their efforts to capture the particular dynamics of corporate governance regulation. In light of the space here available, the following list shall highlight the aspects that such a perspective-building process has been focusing on:

1. The 'politics' of corporate law-making, meaning the observable policies and programmatic directions of corporate regulation. Corporate regulatory politics have been among the most discussed and contested elements at the heart of the global corporate

${ }^{109}$ G. Jackson, 'Contested Boundaries: Ambiguity and Creativity in the Evolution of German codetermination', in: W. Streeck \& K. Thelen (eds), Beyond Continuity. Institutional Change in Advanced Political Economies, (Oxford: Oxford University Press, 2005), pp. 229-254; R. Boyer, 'What is the Future for Codetermination and Corporate Governance in Germany?', in: J. Beckert, B. Ebbinghaus, A. Hassel \& P. Manow, (eds), Transformationen des Kapitalismus. Festschrift für Wolfgang Streeck zum 60. Geburtstag, (Frankfurt aM-New York: Campus, 2006), pp. 135-157.

${ }^{110}$ See, for example, K. Pistor, 'Codetermination: A Sociopolitical Model with Governance Externalities', in: M. Blair \& M.J. Roe (eds), Employees and Corporate Governance, (Washington DC: Brookings Institution, 1999), pp. 163193.

111 J. Adolff, 'Turn of the Tide? The 'Golden Share' Judgements of the European Court of Justice and the Liberalization of the European Capital Markets', in: (2002) 3 German Law Journal, available at: http://www.germanlawjournal.com/past_issues.php?id=170; P. Zumbansen \& D. Saam, 'The ECJ, Volkswagen and European Corporate Law: Reshaping the European Varieties of Capitalism', (2007) 8 German Law Journal, pp. 10271051.

${ }^{112}$ Kirchner \& Painter, note 81 
governance debate. This debate started long before the well-known cases of corporate mis-management, fraud and accounting manipulation within and around Enron. While this political debate is marked by significant domestic dimensions, a remarkable, comparative perspective has given corporate law scholarship some decisive impulses. The focus has overwhelmingly been on the opposition of the so-called 'insider' versus the 'outsider' model of corporate governance. ${ }^{113}$ While the former signifies the role of firminternal control mechanisms, stakeholders and processes vis-à-vis management, in other words, labour, financial institutions, directors, etc., the latter, the 'outsider' model labels a structure whereby management is held accountable largely through the presence of independent directors and through the securities markets. The global debate over the last fifteen years has been largely concerned with the discernible trends of either pointing towards a worldwide convergence towards a shareholder-oriented model, or of representing different, resisting models defended in an argument favouring divergence. Over the past few years, this debate has differentiated considerably, and today not only are there legions of comparative corporate law publications, but also more and more authors are taking the historical and sociological work explaining the institutional evolution of market structures of different countries into account. ${ }^{114}$ This, in itself, is a remarkable return to an earlier period in which corporate law scholarship, much more generally, displayed a great interest in the political economy of which corporate regulation was a part. ${ }^{115}$

2. The other focus of transnational corporate governance research ${ }^{116}$ has been on the types of norms that regulate corporate behaviour today, on the authors of these norms, the domestic and international, public and private institutions. This part of a faster growing area of regulatory work within corporate and capital market law, ${ }^{117}$ as well as in other very prominent fields, such as standardisation, focuses on the interaction of hard, public, official law-making, on the one hand, and on the private, unofficial, soft normgeneration, on the other. From this perspective, corporate law is transformed into an around-the-clock laboratory for the study of the shift in law-making from public mandate

${ }^{113}$ Hopt 2002, note 96

${ }^{114}$ L. Boltanski \& È. Chiapello, Le nouvel esprit du capitalisme, (Paris: Gallimard, 1999); idem, 'Die Rolle der Kritik für die Dynamik des Kapitalismus: Sozialkritik versus Künstlerkritik', in: M. Miller (ed), Welten des Kapitalismus, (Frankfurt aM-New York: Campus, 2005), pp. 285-321, at 294.

${ }^{115}$ F. Klein, Die neueren Entwicklungen in Verfassung und Recht der Aktiengesellschaft (Vienna: Manz, 1904); Adolf A. Berle \& Gardiner C. Means, The Modern Corporation and Private Property, (orig. New York: Macmillan, 1932; reprint: Brunswick NJ: Transaction Publishers, 1991).

${ }^{116} \mathrm{http} / / /$ www.comparativeresearch.net/projects.jsp.

${ }^{117}$ http://www.sustainablefinancialmarkets.net. 
to private self-regulation, for example, by delegation or appropriation of 'law'-making authority, as illustrated, for example, by the proliferation codes of conduct. Certainly, an important caveat is already in order at this point. Only a comparative perspective on different corporate law-making cultures can open our eyes to the differences of approaches in norm-creation, enactment and enforcement of the regulatory bodies which govern what corporations do today. ${ }^{118}$ Comparativists have long established the remarkable differences in corporate law-making between North America and Europe to be marked, first and foremost, by the difference between enabling law in the U.S. and more mandatory forms of corporate law rules in Europe. This difference is again echoed in other much-referenced contrasts, such as that between common law on one side of the Atlantic, and civil law on the other, with the UK interestingly sitting on both sides of the fence. ${ }^{119}$ In the process of studying the proliferation of corporate law norms, distinctions between enabling and mandatory law, and between common law and civil law, matter, but ongoing research questions the stability and, as such, the long-term sustainability and explanatory force of these distinctions. ${ }^{120}$

3. This has dramatic consequences for the position of corporate law within a larger, highly differentiated, dynamic regulatory environment. Corporate law unfolds in a web of norms, official and unofficial, public and private, from which it receives impulses and to which it sends others - this web is increasingly transnational in both origin and reach. ${ }^{121}$ This is certainly true with regard to the evolving private law culture related to product safety, contract regulation, consumer protection, or, to switch to public law, with regard to the applicable environmental law applicable to corporations. But, there is clearly

${ }^{118}$ R. Dore, W. Lazonick \& M. O'Sullivan, 'Varieties of Capitalism in the Twentieth Century', (1999) 15 Oxford Review of Economic Policy, pp. 102-117.

${ }^{119}$ B.R. Cheffins, 'Putting Britain on the Roe Map: The Emergence of the Berle-Means Corporation in the United Kingdom', in: J.A. McCahery, P. Moerland, T. Raaijmakers \& L. Renneborg, (eds), Corporate Governance Regimes. Convergence and Diversity, (Oxford-New York: Oxford University Press, 2002) 2002, , pp. 147-172; idem, 'Current Trends in Corporate Governance: Going from London to Milan via Toronto', (1999) 10 Duke Journal of Comparative and International Law, pp. 5-42.

${ }^{120}$ See A. Shleifer and R. W. Vishny 1997. 'A Survey of Corporate Governance', The Journal of Finance 52: pp. 737783; for an insightful discussion and critique, see B. Ahlering \& S. Deakin, 'Labor Regulation, Corporate Governance, and Legal Origin: A Case of Institutional Complementarity?', (2007) 41 Law \& Society Review, pp. 865903; A.N. Licht, C. Goldschmidt \& S.H. Schwartz, 'Culture rules: The foundations of the rule of law and other norms of governance', (2007) 35 Journal of Comparative Economics, pp. 659-688, and H. Spamann 2009. 'Contemporary Legal Transplants -- Legal Families and the Diffusion of (Corporate) Law', Brigham Young University Law Review pp. http://ssrn.com/abstract=1411704

${ }^{121}$ http://www.ecgi.org/codes/all_codes.php; http://www.transnationalcorporategovernance.net. 
another set of regulations, which, only nominally, do not figure as a part of corporate law - whether this is by choice or necessity needs to be discussed. Corporations employ a workforce in a dramatically diversifying global division of labour, no longer merely recognisable by the blue collars of some, and the white collars of others. Both today's workforce and the environment in which it is operating have become a subject of study in, and of, itself. Richard Sennett's work on the transformation of work is just one of the more recent illustrations of a far-reaching sociological interest in the fate of workers today. ${ }^{122}$ Labour lawyers have, for a long time, been struggling to re-assert regulatory capacity in the interest of protecting workers' interests in a globalised economy better, where holding a job and working on a project has come to replace long-term employment, without, however, always delivering the accompanying promises of increased control, private autonomy and skills building. ${ }^{123}$ In short, 'work', and its changing face, has become something that corporate lawyers increasingly look to more and more - just as Dean Clark told them to in his 1986 textbook. ${ }^{124}$

\section{B. The New Embeddedness of the Firm: Transnational Corporate Governance as Transnational Legal Pluralism}

Today, regulatory spaces are opened up and continue to expand as a result of complex interactions of processes and ideas, central to whom is the transformation of formal rule creation in politically embedded state legal systems towards a system of specialised transnational law regimes. Such regimes consist of hard and soft laws, which emerge through processes that involve public and private actors, through the experimentation with new rules and their subsequent rejection, transformation and - temporary - solidification. Corporate governance norms provide a telling example of this transformation of traditional stateoriginating, official norm-setting in favour of increasingly de-centralised, spatialised processes of norm production ${ }^{125}$, which can be understood through the concept of 'Rough Consensus and Running Code', originally developed in Internet governance. ${ }^{126}$ The very nature of these norms themselves has been changing dramatically as a result of this new form of transnational

${ }^{122}$ R. Sennett, The Culture of the New Capitalism, (New Haven CT: Yale University Press, 2006); idem, The Craftsman, (London: Allen Lane, 2008).

${ }^{123}$ A. Blackett, 'Codes of Corporate Conduct and the Labour Law Regulatory State in Developing Countries', in: J.J. Kirton \& M.J. Trebilcock (eds), Hard Choices, Soft Law. Voluntary Standards in Global Trade, Environment and Social Governance, (Aldershot: Ashgate Publishing, 2004), pp. 121-133.

${ }^{124}$ Clark, 1986, p. 5.

${ }^{125}$ See, in detail, Calliess \& Zumbansen 2010, note 15, pp. 242-345.

${ }^{126}$ For more background and application, see Calliess \& Zumbansen, note 15. 
embeddedness. Central to the observation in the particular areas that this paper focused on is the particular nature of the regulation of business conduct and corporations in globally interdependent activity spheres (marketisation), fundamentally changing national political economies (privatisation), and a dramatic expansion of issue-driven, functionalist regulatory regimes (scientisation). ${ }^{127}$ This constellation, however, suggests nothing less than a fundamental contestation and erosion of boundaries between state and non-state actors, official and unofficial law, public and private ordering. ${ }^{128}$ Above all, legal theory and doctrine are faced with important methodological challenges. Politics matter still, but they are no longer so easily defined as the politics of 'The Right' or 'The Left', which we learned to distinguish domestically throughout the twentieth century and right up to the recent shock to the financialised global economy. The questions that are raised not only by the commercial, productive, but also the re-distributive, sustainable, R\&D related and routine/innovationrelated activities of corporations do not lend themselves to straight-forward categorisations of either public or private, or of domestic or international. In response to this situation, it is through the study of transnational regulatory regimes that a re-visiting of the political questions and issues that continue to arise around particular regulatory challenges or experiences becomes possible. This study builds on an understanding of transnational law not as a separate field, but as a method and approach to legal reasoning. We must re-think law and regulation without resorting to traditional distinctions in the belief that they will deliver the same explanatory potential that we have grown accustomed to: instead, we must approach emerging institutional regimes from a transnational regulatory perspective. And it is here that comparative corporate law transforms itself into the study of these increasingly deterritorialised corporate governance regimes as an illustration of transnational legal pluralism. Comparative corporate lawyers must search today for the equivalents of and for compatible institutional settings and actors that allow a new turn of the long-standing debates about the corporation.

\footnotetext{
${ }^{127}$ For an excellent demarcation of these dimensions, see G. S. Drori and J. W. Meyer 2006. 'Scientization: Making a World safe for organizing', in M.-L. Djelic and K. Sahlin-Andersson (eds), Transnational Governance. Institutional Dynamics of Regulation. Cambridge, UK, Cambridge University Press, pp. 31-52.
}

${ }^{128}$ See, for example, V. Gessner, R. P. Appelbaum and W. F. Felstiner 2001. 'Introduction: The Legal Culture of Global Business Transactions', in V. Gessner, R. P. Appelbaum and W. F. Felstiner (eds), Rules and Networks: The Legal Culture of Global Business Transactions. Oxford/Portland, OR, Hart Publishing, pp. 1-36; V. Gessner 2009. 'Theories of Change - The Governance of Business Transactions in Globalising Economies', in V. Gessner (ed) Contractual Certainty in International Trade. Empirical Studies and Theoretical Debates on Institutional Support for Global Economic Exchanges. Oxford, UK/Portland, OR, Hart Publishing, pp. ; F. Snyder 2004. 'Economic Globalisation and the Law in the 21st Century', in A. Sarat (ed) The Blackwell Companion to Law and Society. New York \& Oxford, Blackwell, pp. 624-640; K. Pistor 2003. 'Of Legal Transplants, Legal Irritants, and Economic Development', in P. Cornelius and B. Kogut (eds), Corporate Governance and Capital Flows in a Global Economy. Oxford/New York, Oxford University Press, pp. 347-366. 